\title{
Use of Benthic Macro Invertebrates as a Biological Indicator in Assessing Water Quality of River Puyo, Puyo, Pastaza, Ecuador
}

\author{
Mariadoss Selvanayagam ${ }^{1,2,}$, Ricardo Abril ${ }^{1}$ \\ ${ }^{1}$ Department of Environmental Engineering, Universidad Estatal Amazónica, Puyo, Pastaza, Ecuador \\ ${ }^{2}$ Loyola-ICAM College of Engineering and Technology (LICET), Loyola Campus, Chennai, India \\ Email address: \\ selvam.mariadoss@gmail.com (M. Selvanayagam), ricardo.abril.saltos@gmail.com (R. Abril)
}

\section{To cite this article:}

Mariadoss Selvanayagam, Ricardo Abril. Use of Benthic Macro Invertebrates as a Biological Indicator in Assessing Water Quality of River Puyo, Puyo, Pastaza, Ecuador. American Journal of Life Sciences. Vol. 4, No. 1, 2016, pp. 1-12. doi: 10.11648/j.ajls.20160401.11

\begin{abstract}
There is an increased need for water conservation and protection for the sustainable livelihood of human beings as well as for the goodness of our environment. There is a greater awareness among the researchers, and Government organizations in the conservation of water resources in Central Amazonia region particularly in Ecuador. We have taken water sample from eight different sampling stations in the river Puyo, one of the major tributaries of river Amazon in South America. So far, no work has been carried out on the water quality of river Puyo to understand the biodiversity of macroinvertebrates and use of the same in the water quality assessment. Our final index included five matrices, namely Biotic index, Ephemeroptera,-Plecoptera-Trichopters (EPT) richness as richness measures, EPT and Chironomidae ratio, H' and evenness (Hmax) to understand the water quality. We have also studied the physico chemical characteristics of water and coliform bacteria to assess the quality of water. All the values obtained reflect the quality of water in the sampling stations $1,2,3,6$, and 7 , which are in the upstream located in the high altitudes as well as in the forest area, are better than the other three sampling stations 4, 5 and 8, which are located in the downstream in the urban area. In general, all the five sampling stations indicated more or less good water quality while the other three stations $(4,5$ and 8$)$ showed deterioration in water quality and thus necessitated a need for mitigation measure to save the Puyo river. The various metric values are ( $p$ value is $>0.05)$.
\end{abstract}

Keywords: Puyo, Benthic Macroinvertebrates, Biological Indicator, Biotic Index, Coliform Bacteria

\section{Introduction}

As we discuss Internationally more and more about the world threatening factors namely climate change and Global warming, we cannot ignore its threat posed to the Biodiversity and sustainable livelihood of communities. Our aquatic ecosystems are fast deteriorating due to various anthropogenic activities.Aquatic macroinvertebrates are ubiquitous, and their sensitivity to environmental changes makes them good indicators of water quality. Diversity and biotic indices for benthic macroinvertebrate samples are often applied in an attempt to measure river pollution [1]. According to Thuiller [2] Global change, population growth, and industrial development are currently exerting much impact on natural ecosystems, especially on aquatic systems. Kaufman [3] explains in 'Catastrophic Change in Species rich Freshwater Ecosystems', how agricultural practices, livestock and domestic discharges, felling of trees, exotic species introductions, and direct erosion have caused increase in the organic matter and suspended solids in water, resulting in strong alterations in the ecological functioning of aquatic systems.

The anthropogenic disturbances strongly affect the species richness of aquatic macroinvertebrates [4]. Hynes [5] has discussed how aquatic insects such as Ephemeroptera, Plecoptera, Trichoptera, Coleoptera (EPTC) are known to be pollution sensitive. Conventionally, the water quality monitoring is based on preselected chemical-physical evaluation, which has been considered insufficient by developed country as it only monitors the quality of the water based on chemical-physical aspect but neglecting the complex condition of the ecosystem itself. The purpose is to protect the ecosystem in order to secure the process that gives the clean water. Biotic indices are tools for the sustainable management of water resources. They provide a coherent classification of water quality and also allow for the 
systematic evaluation of water quality degradation (e.g., excellent to poor) or improvement following mitigation or rehabilitation measures (poor or regular to good and excellent) (e.g., Macroinvertebrate) indices have been developed recently for the evaluation of aquatic environments in hydrographic basins in south eastern Brazil [6]. As biomonitoring is introduced to evaluate ecosystem health and one of it is by using benthic macroinvertebrates as an add on component to evaluate environment condition, supporting the current method as it can be utilised to evaluate the complex interaction of various parameters or organisms which were not covered by the traditional method, which may lead to spatial discontinuities in predictable gradients [7] and losses of taxa [8]. Resh and Jackson [9] noted that species richness is susceptible to the impact of human activities on stream ecosystems, particularly on aquatic insects of the orders. It has been [10] showed the pertinence of EPTC species associations for stream classifications. Wallace [11] have noticed that species richness of Ephemeroptera, Plecoptera, Trichoptera actually responds to variations in water quality.

In most of the developed countries like Australia and the United States and countries in the European Community, the biological evaluation of rivers and streams is a Government obligation and it is regulated by federal laws [12]. These evaluation complement physical and chemical characteristics and because aquatic organisms interact with the aquatic environment during most or all of their lives, the evaluation also provide information about environmental stresses that preceded the sampling [4]. Most of the river and stream ecosystems have relatively diverse macroinvertebrates assemblages with species from several orders mainly Ephemeroptera, Trichoptera, Plecoptera, Coleopteran, Dipterans. Each species is to some degree unique and as a result each potentially possesses different tolerance to change in environmental conditions. Hence, aquatic macroinvertebrates are very sensitive to measure of environmental changes and stress of the aquatic ecosystem. The other advantage is that they have very limited mobility and spend relatively long life spans (many months to many years) make the presence or conspicuous absence of macroinvertebrate species at a site a meaningful record of environmental quality. Moreover they play a very important role in the food web functioning as primary consumer (herbivores and detritivores). Hence the use of macroinverterates as a biomonitoring tool has been well accepted throughout the world for effective monitoring of water quality.

Kazlauskas [13-15] has investigated stoneflies (Plecoptera), (Caddisflies) Trichoptera and mayflies (Ephemeroptera) in different types of (medium-sized among them) in Lithuanian rivers. Past study has proved the pollution-stress related between benthic macroinvertebrates and its surrounding environment [16] and many studies have been conducted to see into this matter in pristine river in Malaysia [17, 18].

One of the most commonly used index is the BMWP (and its derivations), which was developed in 1978 by the Biological Monitoring Working Party (BMWP) in the United Kingdom [19]. This index gives a score to each taxa according to the sensitivity of pollution being the most sensitive taxa scored with values of 10 and the less sensitive (or more resistant) to pollution a score of 1.It has been adapted by many countries such as Poland, Canada, Thailand and Spain and modified versions of this is used other countries such as Portugal and Greece as a monitoring tool [20].

Water pollution is a serious problem in most of the developing countries of the world. Global change, population growth and industrial development are currently exerting great pressure on natural ecosystem especially on the aquatic ecosystem [21]. Fresh water ecosystems represents a major group of habitats around the world. Many researchers have studied the causes and effects of pollution in tropical rivers, mainly with respect to particulate and suspended matter, the chemical dynamics in water connected with organic matter content, nutrient loading, and $\mathrm{pH}$. In the developing countries, like Latin America, most of the rivers pass through a strong degradation in the quality of water due to over exploitation of the resources and pollution. In Ecuador, only about $5 \%$ of the waste water is subjected to treatment [22]. Even though the water law in Ecuador prohibits the sewage discharge into rivers and lakes (in Title of the Conservation and Water pollution Chapter II Article 22) [6], in Puyo there is no consistent waste water treatment and hence the deterioration of the river water quality increases day by day.

The water quality assessment of river water has been carried out with the implementation of water Framework directive (WFD) every EU member state is obligated to assess the effect of human activities on the ecological quality of all water bodies [23].

Aquatic macroinvertebrates are ubiquitous, and their sensitivity to environmental changes make them good indicators of water condition. These macroinvertebrates are used to describe the stream and watershed health based on the biological integrity of the macro-invertebrates fauna. Benthic macro-invertebrates are cost effective, commonly used, and widely accepted tool in [24, 12]. There are several studies that have used macroinvertebrate communities to assess the effect of organic waste on the coastal streams of South American countries. Most of them have been carried out in Colombia, Chile, Argentina, Uruguay, Peru, Brazil and Bolivia but only few in Ecuador and none in coastal streams $[25,26]$ of tropical Amazon region.

The EPT Index uses three orders of aquatic insects that are easily sorted and identified and is commonly used as an indicator of water quality. The EPT Index is named for three orders of aquatic insects that are common in the benthic macroinvertebrate community: Ephemeroptera (mayflies), Plecoptera (stoneflies), and Trichoptera (caddisflies). The EPT Index is based on the premise that high quality streams usually have the greatest species richness. Many aquatic insect species are intolerant of pollutants and will not be found in polluted waters. The greater the pollution, the lower 
the species richness expected, as only a few species are pollutant tolerant.

The small invertebrates are functionally important in many terrestrial and aquatic ecosystems [27-30]. In freshwater sediments, benthic invertebrates are diverse and abundant, but they are often patchily distributed and relatively difficult to sample, especially when they live in deep subsurface sediments. Thus, the species richness and functional importance of fresh-water benthic invertebrates generally go unnoticed until unexpected changes occur in ecosystems. Unanticipated changes in freshwater eco-systems are often due to alterations in the complex connections among sediment-dwelling species and associated food webs [31-33] or to disturbances, such as floods or drought [34-36], that alter the species composition of the benthos. The primary task in biomonitoring is the search for the ideal indicator or (bioindicator) whose presence, abundance, and/or behaviour reflects a stressor's effect on biota [37]. Historically, invertebrates have received considerable attention in the study of running water ecosystems, in particular relationships between macroinvertebrate community structures and environmental variables have been the subject of numerous investigations [38-44].

Benthic macroinvertebrates are the animals that lack a back bone and generally are visible with the naked eye, and are sensitive indicators of environmental changes in streams because they express long term changes in water and habitat quality rather than instantaneous condition [45]. Anthropogenic activities, such as habitat modification, pollution and the over exploitation of living resources, continue to have a detrimental effect on global biodiversity levels and the subsequent provision of ecosystem services $[46,47]$. Biological monitoring is generally used to examine existing stream conditions. The biological approach for assessing streams and rivers is the use of benthic macroinvertebrates, especially aquatic insects, as indicators of pollution [48]. The use of benthic macroinvertebrates is wide spread and constitutes the basis for most aquatic biomonitoring programs currently in use [4, 49]. Macroinvertebrate Diversity / Ecology sensitive measure of environmental change and stress. Second, their limited mobility and relatively long life spans (a few months to a year or more) make the presence or conspicuous absence of macroinvertebrate species at a site a meaningful record of environmental quality during the recent past, including shortterm infrequent events that might be missed by periodic water sampling or avoided by more mobile/migratory fish. Third, aquatic macroinvertebrates are an important link in the food web, functioning as primary consumers (herbivores and detritivores) of plant and microbial matter that are then available to secondary consumers such as fish. Fourth, their abundance lends itself to statistical analysis, which can play an integral role in water quality assessment programs. Finally, aquatic macroinvertebrates have proven to be effective tools for communicating water and watershed issues to students, decision makers, and the public. Benthos are one of the best biological indicators of water quality monitoring their presence or absence provides a reliable picture of the river ecosystem. Macroinvertebrate organism forms an integral part of an aquatic environment with ecological and economic importance as they maintain various levels of interaction between the community and the environment. Benthos are important bio indicators because of their limited locomotors abilities, their attachment to solid substrates, and their relatively long life cycles. Thus, these organisms are well suited for monitoring water quality in flowing water.

The Neotropical region has long been recognized as supporting one of the highest levels of biological diversity in the world. Insects are particularly abundant and species rich in many Neotropical ecosystems, yet the extent of this diversity, the factors that govern its distribution and the degree of degradation as a result of anthropogenic changes are still incompletely known.

Jacobsen [50] explains the effect of organic pollution on the macroinvertebrate fauna of Ecuadorian highland streams. There is a strong water quality degradation gradient in Latin America and it is due to increasing exploitation of the resources and the excessive water pollution especially in Ecuador where only $5 \%$ of the wastewater in the region is subjected to some type of treatment. Even though the water law establishes the prohibition of sewage discharges in rivers and lakes (in Title II of the Conservation and Water Pollution Chapter II Article 22) by Carlos Martinea-Saz et al., [6]. Feminella \& Resh [25] and [26], have explained how in streams, species richness of macroinvertebrates is affected by a large number of biological and environmental factors.

The main objective of the present study is to make the biosurvey of Puyo river in Puyo, Pastaza on macroinvertebrates with special reference to EPT index with Eight stations namely Fatima, Los America, UEA, Obrero, Picolina, Pindo Mirador, Union Base, and Santo Domingo located both in the forest and urban areas of Puyo.

\section{Material and Methods}

\subsection{Sampling Stations}

Eight sampling stations were established along the stretches of the Puyo river, Fatima (station 1), Los America (station 2), UEA (station 3), Obrero (station 4), Picolina (station 5), Pindo mirador (station 6), Union Base (station 7), and Santa domingo (station 8). Table 1 shows the details of samplings stations latitude, longitude and altitude. Station 1. $2,3,6$, and 7 are located in the forest and in high altitude while the stations 4,5 and 8 are located in the Puyo cityUrban area.

It order to assess the water quality we have taken three important factors namely Physical and Chemical characteristics of water and Biological factors. The physical characteristics include, temperature, total settlable solids and total suspended solids, while the chemical characteristics include dissolved oxygen, $\mathrm{pH}$, conductivity, oxygen saturation; and biological characteristic include the Coliform bacteria and macroinvertebrates. 
Table 1. Location of sampling stations in Puyo River.

\begin{tabular}{|c|c|c|c|c|c|}
\hline S. No & Sampling station & Latitude & Longitude & Altitude & Zone characteristic \\
\hline 1 & Fatima & $-1^{\circ} 434695 \mathrm{~S}$ & $-78^{\circ} 003710 \mathrm{~W}$ & $1034 \mathrm{~m}$ & stony \\
\hline 2 & Los America & $-1^{\circ} 505148 \mathrm{~S}$ & $-77^{\circ} 972521 \mathrm{~W}$ & $924 \mathrm{~m}$ & stony \\
\hline 3 & UEA & $-1^{\circ} 468313 \mathrm{~S}$ & $-77^{\circ} 995881 \mathrm{~W}$ & $932 \mathrm{~m}$ & stony \\
\hline 4 & Obrero & $-1^{\circ} 484881 \mathrm{~S}$ & $-77^{\circ} 991854 \mathrm{~W}$ & $928 \mathrm{~m}$ & stony \\
\hline 5 & Picolina & $-1^{\circ} 495469 \mathrm{~S}$ & $-78^{\circ} 013217 \mathrm{~W}$ & $917 \mathrm{~m}$ & sandy \\
\hline 6 & Pindo Mirador & $-1^{\circ} 457805 \mathrm{~S}$ & $-78^{\circ} 079060 \mathrm{~W}$ & $1135 \mathrm{~m}$ & Rocky \\
\hline 7 & Union Base & $-1^{\circ} 527381 \mathrm{~S}$ & $-77^{\circ} 970819 \mathrm{~W}$ & $900 \mathrm{~m}$ & sandy \\
\hline
\end{tabular}

\subsection{Water Sampling}

Water samples for Physico Chemical analysis were collected using polyethylene bottles which had thoroughly been washed and cleaned. The water was obtained just about $20 \mathrm{~cm}$ below the water surface and immediately transferred to the lab and stored in at below $4{ }^{\circ} \mathrm{C}$ until analysed. The $\mathrm{HACH}$, HOd portable meter, DOC 022.97.-80017 was used to measure the dissolved oxygen, $\mathrm{pH}$, conductivity, saturated oxygen and ORP in the field. The total suspended solids and settleable solids were estimated following the standard procedure [51].

\subsection{Water Sampling for Bacteriological Study}

The water sample for bacteriological analysis were carefully collected in sterilized glass bottles without contamination. Samples were then stored on ice to slow down metabolic activities of bacteria. The colony counting method was used for determining the total faecal Coliform bacteria [51].

\subsection{Coliform Bacterial Study}

Collection of water samples:

Water samples were drawn in sterile $500 \mathrm{ml}$ bottles from the three different sites of river in each occasion of sampling. The water sample were brought to the laboratory in ice box at temperature below $4{ }^{\circ} \mathrm{C}$ within two hrs of sampling.

The water samples collected from different stations of the river were analysed and the total bacterial count (TBC) was determined. The medium used for culture is Coliform Agar for micro-biology, Merck KGaA64271, Darmstadt, Germany. The amount of water sample used for inoculation were $0.1 \mathrm{ml}, 0.05 \mathrm{ml}$ and $0.01 \mathrm{ml}$ and the plates were incubated at $37^{\circ} \mathrm{C}$ for $48 \mathrm{hrs}$. After incubation the petri plates were observed for distinct colonies, counted, tabulated and multiplied by 10, 20 and 100 respectively to get the total number of colony.

\subsection{Macroinvertebrates Sampling}

Intensive collections were carried out both in the side's as well in well of the river for macroinvertebrates. The hand net the size of $200 \mathrm{~mm}$ used with ten sweeps of the net. The hand picking method is also used for the collection of macroinvertebrates. The specimens were transferred in to
$250 \mathrm{ml}$ containers on site and preserved with $4 \%$ formalin for further study and identification.

In the laboratory the specimens were washed and the organisms were then examined under dissecting microscope and identified to the family of genus level, following the procedure of [52-56]. The biotic index, EPT index and EPT/EPT \& Chironomidae index were calculated following the procedure of [52] and Shannon-Wiener Diversity Index $\left(H^{\prime}\right)$ and evenness (Hmax) following the procedure [57]. Reference water quality Index and rating scale of EPT index have been used following the procedure [58]. We have also calculated the Index Biological Monitoring Working Party $\left(\mathrm{BMWP} \mathrm{PBI}^{\mathrm{AB}}\right.$ ) following the procedure of Blanca, [20].

This is the greater robustness index, used in evaluating the quality of water by the composition and structure found macroinvertebrates. Dominguez and Nieto [27] in this modification Casocon ABI [59] and adjusted by the CERA protocol (Ecological Status of Andean Rivers) [60] in order to adapt to local conditions.

\section{Results and Discussion}

\subsection{Physico-Chemical Quality of the Puyo River}

Water quality data generated for all the eight station in river Puyo between December 2014 to March 2015 are given in Fig. 1.

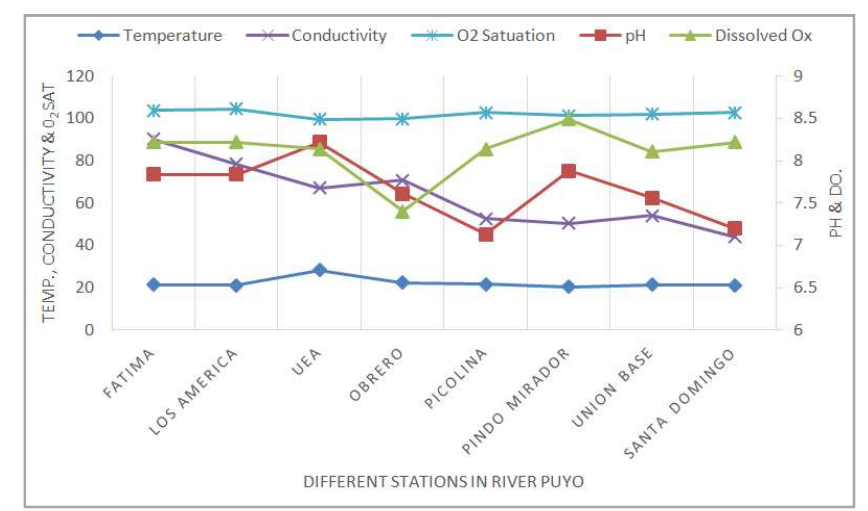

Figure 1. Physico-Chemical characteristic of Puyo River water in different stations.

\subsubsection{Temperature}

The temperature observed in all the eight different stations show variation. The most important source of heat for 
freshwater is generally the sun, although temperature can also be affected by the temperature of water inputs (such as precipitation, surface runoff, groundwater, and water from up-stream tributaries), heat exchanges with the air, and heat lost or gained by evaporation or condensation. Water temperature varies along the length of a river with latitude and elevation, but can also vary between small sections only meters apart, depending on local conditions. The water temperature in station 6 (Pindo Mirador) is lowest $\left(20.4^{\circ} \mathrm{C} \pm 0.70\right)$ situated in the high altitude $(1135 \mathrm{~m})$ in the forest area and other stations show only slight variation. The stations 1, 2, 3, and 7 are showing very slight variation comparing the other three stations namely 4,5 and 8 which are located in the urban areas. This variation is mainly because of anthropogenic activities and discharge of untreated sewage from urban inhabitants [61]

\subsection{2. $\mathrm{pH}$}

The $\mathrm{pH}$ of the water is one of the important factor which influence the life in the aquatic ecosystem. If the $\mathrm{pH}$ of water is too high or too low, the aquatic organisms living within it will die. The $\mathrm{pH}$ can also affect the solubility and toxic of chemicals and heavy metals in the water. The majority of aquatic creatures prefer a $\mathrm{pH}$ range of 6.5-9.0, though some can live in water with $\mathrm{pH}$ levels outside of this range. The more sensitive a species, the more affected it is by changes in $\mathrm{pH}$ In addition to biological effects, extreme $\mathrm{pH}$ levels usually increase the solubility of elements and compounds, making toxic chemicals more "mobile" and increasing the risk of absorption by aquatic life.

The $\mathrm{pH}$ values observed in all the stations vary between $7.13 \pm 0.63$ to $7.96 \pm 0.33$ while in station 3 UEA the $\mathrm{pH}$ value is $8.22 \pm 0.248$. There are many factors that can affect $\mathrm{pH}$ in water, both natural and man-made. Most natural changes occur due to interactions with surrounding rock (particularly carbonate forms) and other materials. The $\mathrm{pH}$ can also fluctuate with precipitation (especially acid rain) and wastewater or mining discharges. In addition, $\mathrm{CO}_{2}$ concentrations can influence $\mathrm{pH}$ levels. Carbon dioxide is the most common cause of acidity in water. Photosynthesis, respiration and decomposition all contribute to $\mathrm{pH}$ fluctuations due to their influences on $\mathrm{CO}_{2}$ levels. Anthropogenic causes of $\mathrm{pH}$ fluctuations are usually related to pollution. Acid rain is one of the best known examples of human influence on the $\mathrm{pH}$ of water. Point source pollution is a common cause that can increase or decrease $\mathrm{pH}$ depending on the chemicals involved. These chemicals can come from agricultural runoff, wastewater discharge or industrial runoff. Mining operations (particularly coal) produce acid runoff and acidic groundwater seepage if the surrounding soil is poorly buffered. Wastewater discharge that contains detergents and soap-based products can cause a water source to become too basic. The $\mathrm{pH}$ value in UEA is $8.22 \pm 0.248$ and it is associated with different type of anthropogenic activities which include Agricultural runoff and water discharge since this station is very close to agricultural area and new settlements.

\subsubsection{Oxygen}

Dissolved oxygen refers to the level of free, noncompound oxygen present in water. It is an important parameter in assessing water quality because of its influence on the organisms living within a body of water. A dissolved oxygen level that is too high or too low can harm aquatic life and affect water quality. The actual amount of dissolved oxygen (in $\mathrm{mg} / \mathrm{L}$ ) will vary depending on temperature, pressure and salinity.

In the present study, the maximum oxygen content was observed in (station 6) Pindo mirdaor where the altitude is $1135 \mathrm{~m}$ and temperature is $20.4^{\circ} \mathrm{C}$, while the least oxygen content was noticed in (station 4) Obrero where the altitude is $928 \mathrm{~m}$ and temperature is $22.4^{\circ} \mathrm{C}$, thus showing the relation between the oxygen content, altitude and the temperature. Moreover in Pindo mirador is a station with lot of rocks and the surface water is disturbed and hence there was a good mixing of atmospheric oxygen to the water while in Obrero, the movement of water is very slow and there a number of developmental activities including tourism, restaurants and inhabitation. The oxygen saturation values are also higher in station 1, 2, 5, 7 and 8, more than $101 \%$ while in stations 3, 4and 6 the Oxygen saturation is less than 101\%.

Among the eight stations in river Puyo the stations 4, 5, and 8 are situated in the urban area and thus they are affected due to mixing of untreated sewage. As such, dissolved oxygen levels can range from less than $1 \mathrm{mg} / \mathrm{L}$ to more than $20 \mathrm{mg} / \mathrm{L}$ depending on how all these factors interact. In freshwater eco systems such as lakes, rivers and streams, dissolved oxygen concentrations will vary by season, location and water depth. The high concentration of Oxygen helps in metabolizing organic matter along the river journey [62].

\subsubsection{Conductivity}

This is an important indicator and measure of the suspended solids, nutrients and therefore can be found in rivers [63]. The conductivity of water in Puyo varies from $44 \mathrm{mv} \pm 3$ to $90.36 \mathrm{mv} \pm 13.23$. Conductivity is a measure of water's capability to pass electrical flow. This ability is directly related to the concentration of ions in the water. The more ions that are present, the higher the conductivity of water. These conductive ions come from dissolved salts and inorganic materials such as alkalis, chlorides, sulphides and carbonate compounds. Compounds that dissolve into ions are also known as electrolytes. The more ions that are present, the higher the conductivity of water. Likewise, the fewer ions that are in the water, the less conductive it is. Conductivity in streams and rivers are affected primarily by the geology of the area through which the water flows. Streams that run through areas with granite bedrock tend to have lower conductivity because granite is composed of more inert materials that do not ionize (dissolve into ionic components) when washed into the water.

On the other hand, streams that run through areas with clay soils tend to have higher conductivity because of the presence of materials that ionize when washed into the water. 
Ground water inflows can have the same effects depending on the bedrock they flow through. The Electrical conductance in the eight stations of river Puyo were found during our study period was $90.36 \mathrm{mv}, 78.34 \mathrm{mv}, 67.263 \mathrm{mv}$, $70.86 \mathrm{mv}, 52.68 \mathrm{mv}, 50.38 \mathrm{mv}, 54.17 \mathrm{mv}$ and $54.17 \mathrm{mv}$ respectively towards the downstream. This observations are similar to the earlier reports given by Alam [65].

\subsubsection{Solids}

Solids refer to matter suspended or dissolved in water. Solids may affect water quality adversely in a number of ways. The Total dissolved solids (TDS) combine the sum of all ion particles that are smaller than 2 microns $(0.0002 \mathrm{~cm})$. This includes all of the disassociated electrolytes that make up salinity concentrations, as well as other compounds such as dissolved organic matter. Depending on the ionic properties, excessive total dissolved solids can produce toxic effects on fish and fish eggs. Dissolved solids are also important to aquatic life by keeping cell density balanced. A sudden increase or decrease in conductivity in a body of water can indicate pollution. Agricultural runoff or a sewage leak will increase conductivity due to the additional chloride, phosphate and nitrate ions. An oil spill or addition of other organic compounds would decrease conductivity as these elements do not break down into ions. In both cases, the additional dissolved solids will have a negative impact on water quality. The concentration of dissolved solids in stream water is important because it determines the flow of water in and out of the cells of aquatic organisms. Also, some dissolved inorganic elements such as nitrogen, phosphorus, and sulphur are nutrients essential for life. In the present study the total suspended solids and settle able solids are vary from station 1 to 8 as shown in the Fig. 2 .

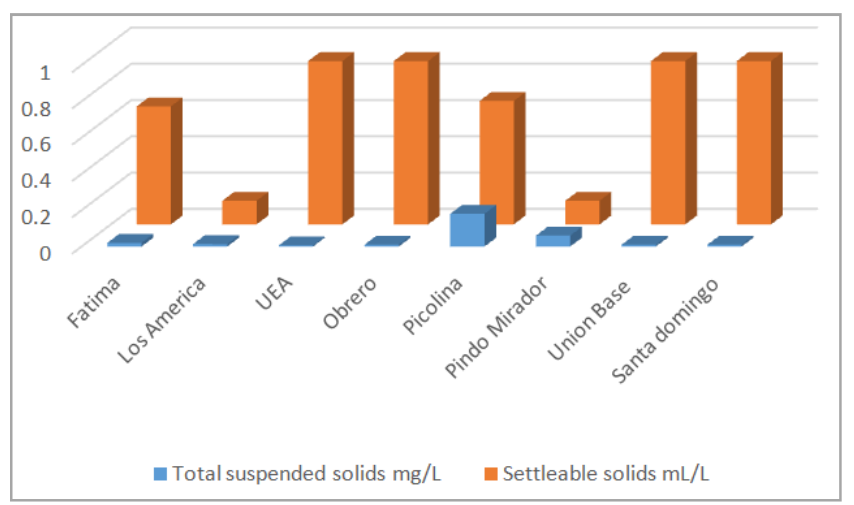

Figure 2. Solids in different Sampling stations in Puyo River.

\subsection{Biological quality of the Puyo River}

\subsubsection{Total Coliform}

Microorganisms are widely distributed in nature, their diversity and density may be used an indicator for the suitability of water [65]. The use of bacteria as water quality indicators can be viewed in two ways. First, the presence of such bacteria can be taken as an indication of faecal contamination of water and second it can be taken as an indication of the potential health risk that faecal contamination poses.

The total number of Coliform counts are given in Fig. 3. It shows a lot of variation among the eight stations of Puyo River in relation to total count of colonies during the period of sampling. In general the total coliform count is higher in stations 4,5 and 8 while the stations 1,2, 3, 6 and 7 are less in coliform. This clearly indicates that they are less polluted. The presence of very less number of coliform in station 1 and 2 are because it is located in the high range and free from different type anthropogenic activities while 4, 5and 8 are situated in the middle of the Puyo city where there are number of untreated sewages enter in to the river. The Total Coliform Bacteria test is the standard microbiological test of the sanitary quality of drinking water. The EPA has stated that good drinking water should not contain any Coliform bacteria. There are primarily 18 different bacteria which make up the group known as "Coliforms". In most cases, Coliform bacteria are not harmful. However, if these bacteria are found in our water supply, this indicates that other disease causing bacteria may enter through the same pathway and be present in our water. E. coli is one of the approximate 18 members of Coliform group. These organisms are prolific in the soil. Their presence does not necessarily imply contamination from wastewater or the presence of other sanitation based health risks. The presence of total coliform by itself does not imply an imminent health risk but does indicate the need for an analysis of all water system facilities and their operations to determine how these organisms entered the water system.

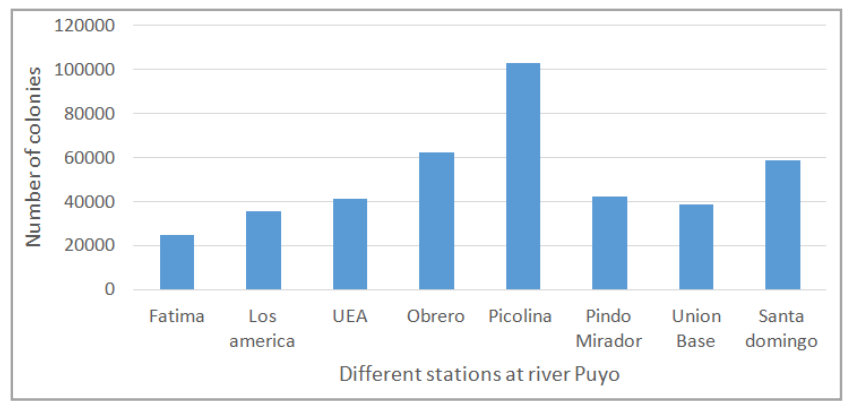

Figure 3. Coliform-Number of colonies.

\subsubsection{Macro Invertebrates}

Aquatic macro invertebrates, among other groups, have been used to develop biotic water quality indices based on sensitive taxa, tolerant taxa or other metrics that represent macroinvertebrates assemblages [66-68]. The total number of different taxa of macroinvertebrates collected in the eight stations of river Puyo is presented in the Table 2. The macroinvertebrate collected in all the eight stations include the following group namely Ephemeroptera, Plecoptera, Trichoptera, Coleoptera, Odonata, Megaloptera, Hemiptera, Diptera, Annelida, Turbellaria and Mollusca. The most important group of Macroinvertebrates namely Ephemeroptera, Plecoptera, Trichoptera, Coleoptera, Megaloptera, Odonata were present more or less in all the stations but Plecoptera was absent in stations 4, 5 and 6 while the Tricoptera was absent only in station 5 , the Odonata was 
absent in station 5, Megaloptera was absent in station 3, 5, 6 and 8 , while Coleopteran was absent in station 4, Hemiptera was absent in stations 4,5 and 8 , Mollusca was absent in stations 1, 2, 4, 5 and 7 and Annelida was absent in stations 1,2 , and 5 while the Turbellaria was absent in stations 1, 2, 4 and 5. If we consider the overall distribution of macroinvertebrates the pollution tolerant groups (Diptera, Annelida and Turbellaria) were seen invariably in the stations located in the urban areas while the sensitive groups
(Ephemeroptera, Plecoptera, Trichoptera and Odonata) were seen in stations which are located in the nonurban areas where the water in unpolluted and free from anthropogenic activities. The Hemipterans were represented only by two families namely Gerridae and Belostomatidae which are mostly found in fast running and unpolluted water stations namely Fatima, Las America, UEA, Pindo Mirador and Union Base.

Table 2. Presence and Absence of different group of Macroinvertebrates in different stations.

\begin{tabular}{|c|c|c|c|c|c|c|c|c|c|}
\hline S. No & Different Macroinvertebrates & Fatima & Los America & UEA & Obrero & Picolina & Pino mirador & Union Base & Santo Domingo \\
\hline 1 & Ephemroptera & YY & YY & YY & YY & YY & YY & YY & YY \\
\hline 2 & Plecoptera & $\mathrm{Y}$ & YY & YY & $\mathrm{N}$ & $\mathrm{N}$ & $\mathrm{N}$ & YY & $\mathrm{Y}$ \\
\hline 3 & Trichoptera & YY & YY & YY & $\mathrm{Y}$ & $\mathrm{N}$ & $\mathrm{Y}$ & YY & $\mathrm{Y}$ \\
\hline 4 & Odonata & $\mathrm{Y}$ & YY & YY & $\mathrm{Y}$ & $\mathrm{N}$ & $\mathrm{Y}$ & $\mathrm{Y}$ & $\mathrm{Y}$ \\
\hline 5 & Megaloptera & $\mathrm{Y}$ & $\mathrm{Y}$ & $\mathrm{N}$ & $\mathrm{Y}$ & $\mathrm{N}$ & $\mathrm{N}$ & $\mathrm{Y}$ & $\mathrm{N}$ \\
\hline 6 & Coleoptera & YY & YY & YY & $\mathrm{N}$ & $\mathrm{Y}$ & $\mathrm{Y}$ & $\mathrm{Y}$ & $\mathrm{Y}$ \\
\hline 7 & Hemiptera & $\mathrm{Y}$ & $\mathrm{Y}$ & YY & $\mathrm{N}$ & $\mathrm{N}$ & $\mathrm{Y}$ & YY & $\mathrm{N}$ \\
\hline 9 & Mollusca & $\mathrm{N}$ & $\mathrm{N}$ & $\mathrm{Y}$ & $\mathrm{N}$ & $\mathrm{N}$ & $\mathrm{Y}$ & $\mathrm{N}$ & YYY \\
\hline 10 & Annelida & $\mathrm{N}$ & $\mathrm{N}$ & $\mathrm{Y}$ & YY & $\mathrm{N}$ & YY & $\mathrm{Y}$ & YYY \\
\hline 11 & Turbellaria & $\mathrm{N}$ & $\mathrm{N}$ & YY & $\mathrm{N}$ & $\mathrm{N}$ & $\mathrm{Y}$ & $\mathrm{Y}$ & $\mathrm{Y}$ \\
\hline
\end{tabular}

$\mathrm{Y}=$ Few $\mathrm{YY}=$ More number, $\mathrm{YYY}=$ Greater number, $\mathrm{N}=\mathrm{Absent}$

Table 3. Different Index for Macroinvertebrates.

\begin{tabular}{lllllll}
\hline S. No & Station & Biotic Index & EPT $\%$ & EPT \& C & H' & \multicolumn{1}{c}{ Hmax Evenness } \\
\hline 1 & Fatima & $3.583 \pm 0.03$ & $75.02 \pm 13.78$ & $0.94 \pm 0.05$ & $1.56 \pm 0.58$ & $0.846 \pm 0.18$ \\
2 & Los America & $3.59 \pm 0.53$ & $69.15 \pm 16.74$ & $0.90 \pm 0.090$ & $1.52 \pm 0.23$ & $0.70 \pm 0.11$ \\
3 & UEA & $3.94 \pm 0.25$ & $71.12 \pm 13.23$ & $0.946 \pm 0.05$ & $1.47 \pm 0.465$ & $0.718 \pm 0.16$ \\
4 & Obrero & $4.63 \pm 1.23$ & $61.96 \pm 24.32$ & $0.86 \pm 0.17$ & $0.953 \pm 0.196$ & $0.577 \pm 0.15$ \\
5 & Picolina & $5.41 \pm 1.46$ & $39.14 \pm 32.33$ & $0.43 \pm 0.302$ & $0.91 \pm 0.401$ & $0.740 \pm 0.27$ \\
6 & Pindo Mirador & $4.49 \pm 0.87$ & $70.96 \pm 22.92$ & $0.87 \pm 0.08$ & $1.36 \pm 0.49$ & $0.73 \pm 0.268$ \\
7 & Union Base & $4.74 \pm 1.20$ & $56.87 \pm 36.93$ & $0.68 \pm 0.16$ & $1.418 \pm 0.934$ & $0.68 \pm 0.364$ \\
8 & Santo Domingo & $5.81 \pm 0.23$ & $30.159 \pm 23.43$ & $0.63 \pm 0.23$ & $2.07 \pm 0.024$ & $0.99 \pm 0.31$ \\
\hline
\end{tabular}

Note: Each value represents the average of five replicates $(n=5)$

The macroinvertebrates diversity among the sampling stations estimated using the biotic index (BI), EPT index and EPT/EPT \& Chironomidae index were calculated following the procedure of $[52,56]$ Shannon-Wiener Diversity Index (H')-following [57] and BMWP ${ }^{\mathrm{ABI}}$ [20]. Table 3. The Shannon's diversity index was lowest $\left(\mathrm{H}^{\prime}=0.953 \pm 0.196\right.$ and $0.91 \pm 0.401)$ in stations Obrero and Picolina respectively while the highest Shannon's diversity index ( $\mathrm{H}^{\prime}=$ $2.07 \pm 0.024)$ was recorded in the station 8 Santo Domingo. According to [69] if the value is less than 1 it is polluted, if it is between 1 to 2 the water is said to be moderately polluted and if it is more than 2 not polluted. Therefore the waters in station $1,2,3,6,7$, and 8 are seems to be good while in stations 4 and 5 needs immediate steps to prevent further deterioration of river water by taking adequate preventive measures. The EPT index for station 5 (Picolina) is $39.14 \pm 32.33$ station 8 Santo Domingo is $30.159 \pm$ which indicate the deterioration in the quality of the water while in the other stations the EPT index were higher than $56.87 \pm 36.93$, thus it clearly indicates that the water quality in stations 1, 2, 3, 4, 6 and 8 are good. Even though the $\mathrm{H}^{\prime}$ value for station 8 is higher 2.07, the EPT value seems to be very low 30.15. The main reason for low EPT index is mainly because, this station is mostly sandy in nature without rocks and does not provide good habitat for the macroinvertebrates and prone for frequent flooding. The other stations are obvious due to pollution effects. The metric values are $(\mathrm{p}>0.05)$.

\subsubsection{Taxa Richness}

Richness of EPT taxa is widely used to evaluate anthropogenic impacts in aquatic ecosystems [70, 71 and 12].The taxa richness is the measure and is a count of the number of taxa found in the sample. From the Fig. 4 it is evident that the Ephemeroptera dominates in all the stations irrespective of the type of boulders and soil type. It is followed by Coleoptera and Plecoptera and then by Trichoptera. The number of Coleopterans found are mostly from stations located in forest area namely Fatima, Los America, UEA, Pindo mirador and Union Base. Thus the abundance of Coleoptera can be correlated to the wilderness of the forest. The substrate of the first three stations and station 6 and 7 are mostly with boulders, cobbles and gravel and the species of Ephemeroptera, Plecoptera and Trichoptera are able to thrive successfully by clinging or attaching to the bottom of the rocks and feeding on the 
organic matter. It has been reported by many authors that Ephemeroptera, Plecoptera and Trichoptera Taxa (EPT Index) are reliable index sensitive to change in stream water and / or substrate quality $[72,73]$. The EPT index is clearly indicate the quality of water from the station 1 to 8 depending up on the position of the river either in the forest region or in the urban area showing the relationship between the quality of water and the anthropogenic activities like Industrial and Agricultural.. The presence of Diptera specially the Chironomous larvae are the indicator of organic pollution. Among the eight stations studied, the Chironomous larvae were the second largest in population in the station 4,5 , and 8 . These three stations are located in the urban area where sewage water is mixing with river water directly without any pre-treatment. Therefore, these three station are in deteriorated condition needs a special attention from the public health authority of the Government for effective control and prevention of pollution. The presence of Gastropoda, Annelida and Turbellaria are indication of deterioration in the quality of water due pollution. Gastropoda, Diptera and Hirudenea (Annelida) have capability to adapt to varied aquatic habitats due to their extra ordinary structural organisation [74, 75-77]. The metrics EPT was included to evaluate the biological condition of Atlantic Forest stream [78]. The \% Chironomidae metric included in the water-quality index proposed by [72], for stream in the Bolivian Amazon was also included in our study for validation. Chronomidae, and consequently Diptera are the most common group found in all the Eight stations but very few in station 1, 2, 3 and 6 indicating the relationship between the human population and dipterans Larvae, suggesting the food relationship between the different Dipteran forms and human population and similar observations were also made by [79]. The EPT/Chironomidae is one of metrics that characterizes the community, representing the proportion between sensitive and tolerant taxa and providing consistent information with respect to the fauna and stream conditions. This EPT/Chrinomidae metric efficiently corroborated in the observation of [12, 79]. According to [12] the biota organizes itself in response to environmental circumstances. Accurate bioassessment of streams depends on having a good knowledge of the natural variation in the structure of the assemblage, with environmental impact or stress being indicated by deviation from the expected reference levels [80]. In accord with the river continuum concept of [81] some biotic metrics can vary naturally with stream size in the watershed. It is apparent from the study that the quality of the river water deteriorated as one moved to downstream and this was mainly because of different type of anthropogenic activities. Seasonal changes can also modify the value of environmental variable such as temperature, organic matter availability and other factors that can influence macroinvertebrate fauna $[12,82-84$.].

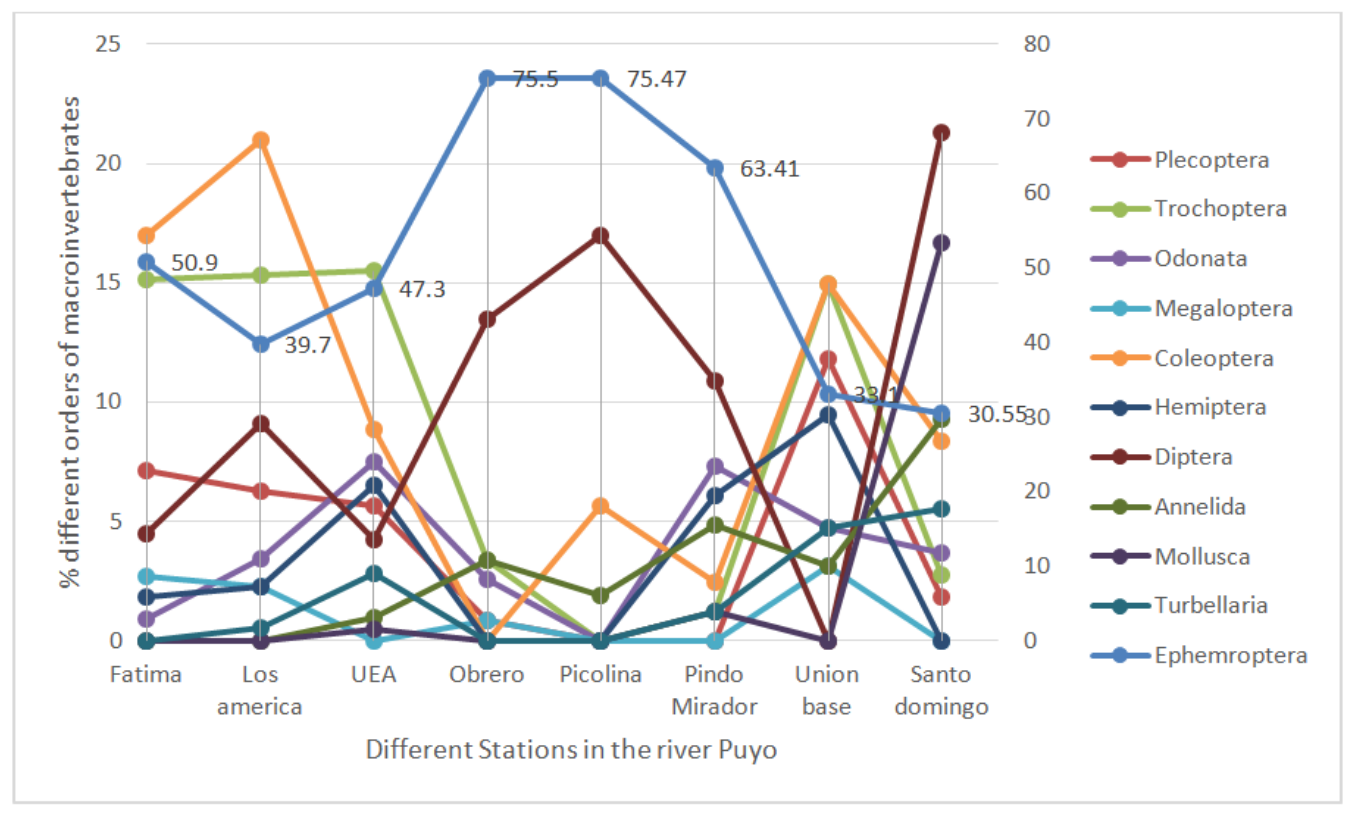

Figure 4. \% Major macroinvertebrates orders in different stations of River Puyo.

\subsubsection{Index Biological Monitoring Working Party $\left(B M W P^{A B I}\right)$}

This is the greater robustness index, used in evaluating the quality of water by the composition and structure found benthic macroinvertebrates [57], in this modification Casocon ABI (Andean Biotic Index [25,] and adjusted by the CERA protocol (Ecological Status of Andean Rivers [60] in order to adapt to local conditions.
The index analyzes the composition of aquatic macro zoo benthos family level and according to their tolerance to pollution, assigning a score to each family according to their ability to survive at various levels of contamination: 10 to more sensitive or less tolerant and 1 tolerant or resistant. The final score is obtained by summing the values of all components of each sample and determining the water quality [85]. 
According to [48] the biota organizes itself in response to environmental circumstances. Accurate bio assessment of streams depends on having a good knowledge, with environmental impact or stress being indicated by deviation from the expected reference levels. According to [12], the choice of metrics to compose a multimetric biotic index based on macroinvertebrates data can lead to erroneous conclusions about the biological condition of a stream ecosystem when the temporal variability of the metrics used to compose the index is not considered by [86, 87]. Some recommendations suggested include an effective and regular sampling occasions during the year is important to understand the other ecological factors like rain fall and flooding. From an economic perspective there is a desire to minimise the frequency of sampling while biological studies needs sampling for more than a year in order to understand the total wholeness of the water quality. It has demonstrated by [88] the benefit of combining datasets from at least two seasons so that rarely recorded in one season are gained from additional season. Furse [89] has showed that combined season data enabled better categorisation and prediction of mcroinvertebrate communities than single season data. In order to understand the whole importance and the role of macroinvertebrates in water quality assessment of river water. Since seasonal changes are a natural phenomenon and it is not possible to give advice on the time period most suitable for sampling. For metric that show seasonal variation the best solution would be to carry out frequent sampling at least thrice in a month so that we could generate more data on the quality of river water by using various macroinvertebrates taxa.

This study seeks to make the baseline of use of taxa richness as bio-indicators and presents the first taxon in this region of Amazon region of river Puyo in the Pasataza province. The limited sample numbers that we were able to get do not allow reaching a concrete conclusion but these results are indicative and it urges the government to take enough and preventive measures to protect the water quality of the river Puyo.

\section{Conclusion}

The River Puyo is one of the major river in Pastaza province and running in the city of Puyo. The present biosurvey was carried out in order to assess the quality of water in river Puyo by using the different taxa of macroinvertebrates. Among the Eight stations studied, the water quality was good in station 1, 2, 3, 6 and 7 than the stations 4, 5and 8. The stations 1, 2, 3, 6 and 7 are located in the forest area, in high altitude and are free from anthropogenic activities including tourism, agriculture and urban sewage pollution mixing. The stations 4,5 and 8 are located in the heart of city-urban areas where there are many domestic sewages joining the river directly without any pretreatment and above all the anthropogenic activities are maximum. This is very much reflected by low EPT values. In these stations there is a degradation due to accumulated organic matter which in turn form a good habitat for the growth of undesirable macroinvertebrates like Diptera larvae, Annelida and Turbellaria.

In view of the deterioration of water quality in the station 4, 5 and 8, the Pastaza Government should take enough preventive measure to protect the water quality. If due measures are not taken in time by the Government this may lead to public health problem which may increase the chance of outbreak of epidemic like Malaria, Chikungunya, Dengue, Cholera and other vector borne and water borne diseases. Therefore it is imperative on the part of Government to take immediate curative step to restore the Puyo river water quality in the above mention stations by suitable preventive and mitigation measures. At present Ecuador was included under the countries which are under the threat of Zika virus. The Aedes sp which is responsible in spreading of Dengue and Chikungunya are also responsible in spreading of Zika virus to people through its bites. The most common symptoms of Zika virus disease are fever, rash, joint pain, and conjunctivitis (red eyes). The illness is usually mild with symptoms lasting from several days to a week. Severe disease requiring hospitalization is uncommon.

In May 2015, the Pan American Health Organization (PAHO) issued an alert regarding the first confirmed Zika virus infection in Brazil. The outbreak in Brazil led to reports of Guillain-Barré syndrome and pregnant women giving birth to babies with birth defects and poor pregnancy outcomes. Zika virus will continue to spread and it will be difficult to determine how the virus will spread over time. In view of this existing menace of virus and mosquito, the Government of Ecuador should take all possible steps to contain the spreading of Zika virus through holistic approach through effective water quality management and clearing the breeding sites of mosquito by fogging and other chemical methods through proper advisory.

\section{Acknowledgements}

The first author acknowledges the Prometeo fellowship received from SENESCYT, Government of Ecuador and also Dr Francis P Xavier SJ., Director, LICET, Loyola Campus, Chennai, India for his continuous support and encouragement. We are also thankful Dr Julio Cesar Vargas Burgos, PhD, Rector, Universidad Estatal Amazonica, Puyo, Pastaza for providing us infrastructure facilities and encouragement.

\section{References}

[1] P. S. Giller and B. Malmqvis, The biology of streams and rivers, Oxford University press, 1998.

[2] W. Thuiller, "Biodiversity: Climate change and the ecologist", Nature, Vol 448, no. 7153, pp550-552, 2007.

[3] L. Kaufman, "Catastrophic change in species-rich freshwater ecosystems: the lessonsd of lake Victoria" Bio science, vol. 42, pp. 846-858, 1992. 
[4] D. M. Rosenberg, and V. H. Resh. Introduction to freshwater biomonitoring and benthic macroinvertebrates. In: -Osemberg, R M and Resh, V. H. (Eds): Freshwater Biomonitoring and Benthic Macroinvertebrates. Chapman and Hall, New York pp1-9, 1993.

[5] H. B. N. Hynes, The use of invertebrates as indicators of river pollution. Proceedings of the Linnean Society of New South Wales London 170: 165. 169. In: D. M. Rosenberg, V. H. Resh (eds). Fresh-water Biomonitoring and Benthic Macroinvertebrates. London: Chap-man \& Hall, 1957.

[6] M. Sanz, S. M. Puente Garcia, E. R. Rebolled and P. Prado, Macro-invertebrates richness Importance in Coastal Tropical Streams of Esmeraldas(Ecuador)and its use and Implications in environmental Management Procedures, International Journal of Ecology, -Vol. 2014, Article ID 253134, 11 pages, 2014.

[7] J. V. Ward and J. A. Stanford, The serial discontinuity concept of lotic ecosystem in Fontaine, T. D and Bartell, S. M, Ecology of River system. Dr. W. Junk publishers, Dor-drecht. The Netherlands. pp. 29-42, 1983.

[8] J. E. Brittain, and S. J. Saltveit, A review of the effect of river regulation on Mayflies (Ephemeroptera) regulated rivers. Research and Management 3: 191. 204, 1989.

[9] V. H. Resh, and Jackson, J. K. Rapid assessment approaches in benthic macroinvertebrates bio-monitoring studies. Page. 195-233 in: D. M Rosenberg and V. H. Resh (eds), Freshwater biomonitoring and benthic macro-invertebrates, Chapman and Hall, New York, 1993.

[10] J. Cayrou, A. Compin, N. Giani and R. Cereghino, Associations spécifiques chez les macroinvertébrés benthiques et leur utilisation pour la classification des cours d'eau. Cas du réseau hydrographique Adour - Garonne (France). - Ann. Limnol. - Int. J. Lim. 36: 189-202.2000.

[11] J. B. Wallace, J. W. Grubaugh and Whiles, M. R., Biotic indices and stream ecosystem processes: results from an experimental study. Ecological Applications 6: 140. 151. 1996.

[12] N. H. Couceiro, B. R. Forsberg, T. P. Pimentel and S. L. B. Luz. A macroinvertebrates multimetric index to evaluate the biological condition of streams in the central Amazon region of Brazil. Ecological Indicators 18(2012)118-125, 2012.

[13] R. Kazlauskas, Material about the mayflies (Ephemeroptera) in the Lithuanian SSR with description of new species Eurylophella lithuanica Kazlauskas sp. n. and imago Neoephemera maxima (Joly). Biology, Geograhy and Geology 6: 157174, 1959.

[14] R. Kazlauskas, The date on mayflies of the River Oka. Scientific works of Zoological Institute of the Academy of Sciences of the USSR 32: 16417, 1964.

[15] R. Kazlauskas. The new date on mayflies (Ephmeroptera) of Baltic States. Hydrobiological studies III: 147149. 1962.

[16] P. J. Godfrey, Diversity as a measure of benthic macroinvertebrate community response to water pollution. Hydrobiologia, 57, I 11-122, 1978.

[17] C. K. Yap, A. Rahim Ismail, A. Ismail, and S. G. Tan,. Species Diversity of Macrobenthic Invertebrates in the Semenyih River, Peninsular Malaysia. Pertanika J. Agric. Sci. 26, 139146, 2003.
[18] M. Z. Azrina, Yap C K, Rahim Ismail A, Ismail A, Tan S G Anthropogenic impacts on the distribution and biodiversity of benthic macroinvertebrates and water quality of the Langat River, Peninsular Malaysia. Ecotoxicol Environ Saf 64: 3373472006 .

[19] P. Armitage, D. Moss, J. F. Wright, and M. T. Furse, The performance of a new biological water quality score system based on macroinvertebrates over a wide range of unpolluted running-water sites. Water Rese-arch, 17(3). 333-347. 1983.

[20] R. T. Blanca, R. Acosta and N. Prat, The Andean Biotic Index (ABI): revised tolerance to pollution values for macroinvertebrate families and index performance evaluation, Rev. Biol. Trop (Int. J. Trop. Biol, Vol. 62 (suppl 2) 249-273, 2014.

[21] Mariadoss Selvanayagam and Ricardo Abril: Water Quality Assessment of Piatua River Using Macroinvertebrates in Puyo, Pastaza, EcuadorAmerican Journal of Life Sciences, 3930: 167-174, 2015.

[22] Carlos Marinez-Sanz, Sara Maria Paunte-Gracia, Eduardo Rodolfo Rebolledo and Pedro Jimenez-Prado, Macroinmvertebrates Richness Importance in coastal Tropical Streams of Esmeraldas (Ecuador) and its Use and ZImplications in environmental Management procedures, International Journal of Ecology, Vol 2014, article ID 253134, 2014.

[23] European commission, Directive2000 /60/EC of the European Parliament and of the Council-Establishing a framework for Community action in the field of water policy. Brussels, Belgium 23, October of 2000.

[24] C. I. Weber, Biological field and laboratory methods for measuring the quality of surface waters and effluents. Tech. Rep. EPA-670/4-73-001. Environmental Protection Agency, Cincinnati, Ohio, 1973.

[25] J. W. Feminella and V. H. Resh Hydrologic influence, disturbances and interaspecific competition in a stream Caddisfly population, Ecology, 71: 2083-2094, 1990.

[26] Voelz and McArthur. Sensitivity of aquatic Insects species richness to disturbances in the Adour-Garonne stream system (France), Ecological indicator, Vol. 3, issue2, pp135-142, 2000 .

[27] E. M. C. Dominguez, C. Nieto. Ephe-meroptera In E. Dominguez \& H. R. Fernandez (Eds.), Macroinvertebradosbntonicos sudamericanos: systematica y biologia (pp, 55-93). Tucuman:-Fundacion-Miguel Lillo-, 2009.

[28] E. O. Wilson. The Diverisity of Life. Harvard University Press, Cambridge, MA. 464 pages, 1992.

[29] D. W. Freckman, TH. Blackburn L. Brussaard, P. Hutchings MA. Palmer and PVR. Snelgrove. Linking biodiversity and ecosystem functioning of soils and sediments. Ambio 26: 556-562, 1997.

[30] Palmer MA, et al. Biodiversity and eco- system processes in freshwater sediments. Ambio 26: 571-577 1997.

[31] S. Postel, S. Carpenter S. Freshwater ecosystem services. Pages 195-214 in Daily GC, ed. Nature's Services: Societal Dependence on Natural Ecosystems. Washington (DC): Island Press, 1997. 
[32] W. Goedkoop, RK. Johnson. Pelagic - benthic coupling: Profundal benthic com- munity response to spring diatom deposition in mesotrophic Lake Erken. Limnology and Oceanography 41: 636-647, 1996.

[33] D. M. Lodge, Christopher A. Taylor, David M. Holdich, and Jostein Skurdal, Nonindigenous Crayfishes Threaten North American Freshwater Biodiversity: Lessons from Europe, Fisheries, Vol. 25, No. 8, 2000.

[34] RA. Stockley, GS. Oxford, RFC.Ormond. Do invertebrates matter? Detrital processing in the River Swale-Ouse. Science of the Total Environment 210: 427-435.1998.

[35] AP. Covich Water and ecosystems. Pages 40-55 in Gleick PH, ed. Water in Crisis. Oxford: Oxford University Press. 1993.

[36] ME. Power. Floods, food chains, and ecosystem processes in rivers. Pages52, 60 in Jones CG, Lawton JH eds. Linking Species and Ecosystems. NewYork: Chapman and Hall. 1995.

[37] SL. Johnson AP. Covich, TA. Crowl, J. Estrada A, Bithorn, and W. Wurtsbaugh. Do seasonally and disturbance influence reproduction in freshwater atyid shrimp in headwater streams, Puerto Rico? Proceedings of the International Association of Theoretical and Applied Limnology 26: 2076-2081. 1998.

[38] R. S. Thorne, W. P. Williams, The response of benthic macroinvertebrates to pollution in developing countries: a multimetric system of bioassessment, Freshwater Biol. 37, 671-686, 1997.

[39] V. H. Resh, Multiple techniques benefit Berkeley campus creek. Water Protection Techniques 1: 184-187. 1995.

[40] Kazancig, and Girgins. Distribution of Oligochaeta species as bioindicators of organic pollution in Ankara stream and their use in biomonitoring. Tr. J. Zoology., 22, 831998.

[41] J. L. Metcalfe, Biological water quality assessment of running waters based on macro invertebrate communities: history and present status in Europe. Env. Pollution. 60, 101-139, 1989.

[42] C. W. Hickeys, and W. H. Clements. Effect of heavy metals on benthic macroinvertebrate communities in New Zealand streams. Envir. Toxi. And Chem. 17 (11), 23-38. 1999.

[43] M. R. Whiles L. Brockb., C. Franzena and S. C. Dinsmore. Stream invertebrate communities, water quality and land-use pattern in an agricultural drainage basin of northeastern. Env. Management. 26 (5), 563. 2000.

[44] L. D Zweig and F. Rabenic. Biomonitoring for deposited using benthic invertebrates: a test on 4 Missouri streams. Journal of the North American Benthological Society. 20, 643. 2001.

[45] R. K. ohnson, T. Wiederholm and D. M. Rosenberg,. Fresh water Biomonitoring using individual organisms, population and species assemblages of Benthic Macroinvertebrates, eds Rosenberg D. M and V. H. Resh, pp 40-158. Chapman and Hall London, 1993.

[46] M. Loreau, S. Naeem, P.Inchausti, J, Bengtsson, JP, Grime, A. Hector, D.U, Hooper, M.A., Huston, D. G. Raffaelli, D. G., B. Schimd, D, Tilman, and D. A. Wardle,. Biodiversity and ecosystem functioning: current knowledge and future challenges. Science. 294, 804-808, 2001.

[47] J. B. C. Jackson, M. X. Kirby, W. H. Berger, K. A. Bjorndal, L. W. Botsford, B. J. Bourque, R. H. Bradbury, R. Cooke, J.
Erlandson, J. A. Estes, T.P., Hughes, S. Kidwell, C. B., Lange, H. S., Lenihan, J. M., Pandolfi, C. H., Peterson, R. S. Steneck, M. J. Tegner, and R. R. Warner. Historical overfishing and the recent collapse of coastal ecosystems. Science. 293, 629-638, 2001.

[48] D. Dudgeon, Tropical Asian Streams: Zoobenthos, Ecology and conservation, Hong Kong University press, 1999 Biological water quality assessment of running waters based on macro invertebrate communities: history and present status in Europe. Env. Pollution. 60, 101-139, 1989.

[49] J. L. Metcalfe, Biological water quality assessment of running waters based on Macro invertebrate communities: history and present status in Europe.Env.pollution.60: 101

[50] D. Jacobsen, C. Cressa, J. M. Mathooko, -J. M. and D. Dudgeon Macroinvertebrates: composition life histories and production. In: Dudheon, D(Ed), Tropical Stream Ecology. Academic Press, San Diego, pp 65-105, 2008.

[51] APHA. Standard Methods for Examination of Water and Waste-water. 21st Edn, American Public Health Association, Washington, DC., USA, 2006.

[52] Mc Cafferty, Aquatic Entomology: the fisherman's and Ecologist's illustrated guide to insects and their relative. W. Patrick McCafferty, Jones and Barleth, Nature 448 page, 1983.

[53] R. W. Bouchard, Jr, Guide to Aquatic Invertebrates of the Upper Midwest. Regents of the University of Minnesota, Minneapolis, Minnesota. - DelaCu http://wrc.umn.edu/pubs/watersqq/index.htm, 2004.

[54] J. M. Elliott, U. H. Humpesch and T. T. -Macan, Larvae of British Ephemeroptera: a key with Eco-logical notes, FBA Scientific Publication 49, 1988.

[55] Neusa Hamada and Sheyla Regina Marques Couceiro, An illustrated key to nymphs of Perlidae (Insecta: Plecoptera) genera in Central Amazonia. Brazil. Rev. Bras. Entomol. 47, 477-480, 2003.

[56] A. C. Ribeiro-Ferreira, and C. G. Froehlich. Anacroneuria Klapalek, 1909 from Amazonas state, North Brazil(Plecoptera, Perlidae, Anacroneuriinae) Aquatic Insects, 23(3), 187-192, 2001.

[57] K. R. Clarkeanand R. M. Warwick, Change marine communities: an approach to statistical analysis and Interpretatio. Natural environment Research Council, UK, 144 pp1994.

[58] J. L. Wilhm and T. C. Doris. Biological parameters for water quality criteria-Biosciences 18(6), -477-481, 1968.

[59] R. Acosta, Caracterizacion de la com-unidad de macroinvertebrados bentonicios de la Cuenca Altoandina del rio Canete (Lima, Peru). (Trabajo de investigacion del programa del doctoroado y diplomado en studios avanzadosen ecologia). Universidad de Barce-lona, Espana, 2005.

[60] R. Acosta, R. Touma, B. M Rieradevall, and N. Prat. Propuesta de un protocol de evaluacion de la calidad ecologica de rios Andinos(C. E. R. A) ysu aplicion en dos cuencas en Eucador y Peru. Limenetica, 28(1), 35-64, 2009.

[61] J. D. Allan, Stream Ecology: Structure and Function of Running Waters. New York: Chapman and Hall. 1995. 
[62] A. I. Payne. The Ecology of Tropical Lakes and Rivers. Ed. John Wiley and sons Ltd. Great Britain, 1986.

[63] G. Roldán Bioindicación de la calidad del Agua en Colombia. Propuesta para el uso del método BMWP/Col. Ed.Universidad de Antioquia. 2003.

[64] J. B. Alam, M. R.Islam, Z. Muyen, M. Mamun, S. Islam, Water quality parameters along rivers, Int. J. Environ. Sci. Tech, 4 (1): 159-167, 2007.

[65] G. C. Okpokwasili and T. C. Akujobi, Bacteriological indicators of tropical water quality, Environmental Toxicology and Water Quality Volume 11, Issue 2, pages 77-81, 1996.

[66] D. Hering, O.., Moog, and T. Ofenbock, Cook book for the development of a multimetric index for biological condition of aquatic ecosystems: experiences from the European AQEM and STAR projects and related initiatives. Hydrobiologia 566, 311-342, 2006.

[67] F. M. Oliveria, R. L. Araujo, J. S. Carvalho, and S. S Costa, Determinacao da variacao no microclima de Manus-AM por atividades anthropogenicas e modulacoes climaticas naturais. Acta Amaz. 38, 687-700, 2008.

[68] J. L. Stoddard, A. T. Herlihy, D. V. Peck, R. M. Hughes, T. R. Whittier, and E. T. R. Tarquinio, A process for creating multimetric indices for large-scale aquatic surveys. J. N. -Am. Benthol. Soc. 27, 878-891, 2008.

[69] JLWilhm and T. C. Donis Biological parameters for water quality criteria. BioScience 18: 477-81, 1Department of Zoology and Reservoir Research Center, Oklahoma State University 1968.

[70] C. A. Mebane, Testing bioassessment metrics: macroinvertebrate, sculpine, and salmonid responses to stream.

[71] Habitat, sediment and metals. -Environ. Monit-. Assess. -67, 293-322, 2001.

[72] N. Moya, S. Tomanova and T. Oberdorff. Initial development of a multimetric index based on aquatic macroinvertebrates to assess stream condition in the upper Isiboro-Secure Basin, Bolivian Amazon. Hydrobiologia 589, 107-116, 2007.

[73] Lenat and M. T. Barbour, Using benthic macroinvertebrate community structure paid, cost-effective, water quality monitoring; rapid bioassessment. In SL Loeb, a spacie, eds. Biological monitoring of aquatic systems. Boca Raton, FL: Lewis-, pp. 187-215macroinvertebrates. Chapman and Hall, New York, pp 1-9, 1994.

[74] S. Santhosh. C. Krishna Mohan. N. R. Dhanesh and P. Akolkar. Water quality assessment of river Karamana by using Benthic macroinvertebrates, Southern Kerala, India: The Ecoscan 5(3\&4): 135-140, 2011.

[75] P. Tyagi. Occurrence of benthic macro-invertebrates families encountered in river Hindan in Uttar Pradesh (India). J. Zool India 1(9):-209-216, 2006.

[76] I. G. Needhm, P. R. Needham, A guide to the study of fresh water biology. Holdden \& Day San Francisco: 108, 1969.
[77] G. T. Tonapi, Fresh water animals of India: An ecological approach. Oxford and IBH Publishing Co. New Delhi: 341, 1980.

[78] D. F. Baptista D. F. Buss, M. Egler, A. Giovanelli, M. P. Silveria, and J. L. Nessimian, Multimetric index based on benthic macroin-vertebrates for evaluation of Atlantic Forest stream at Rio de Janeiro State, Brazil, Hydrobiologia 575, 8394, 2007.

[79] S. R. M. Couceiro, N. Hamada, B. R. Foresberg, and C. Padovesi-Fonseca. Effects of anthropogenic silit on aquatic macroinvertebrates and abiotic variable in stream in the Brazillian Amazon. J. Soil Sediments 10, 89-103, 2010.

[80] P. Kleine, and S. Trrivinho Strixino, Chironomidae and other aquatic macroinvertebrates of a first order stream: community response after habitat fragmentation, Acta Limnol-. Bras. 17(1). 81-90, 2005.

[81] R. L. Vannote, G. W. Minshall, K. W. Cummins, J. R. Sedell, and C. E. Cushing, The river continuum concept" Canadian Journal of Fish and Aquatic Sciences, vol. -37, no1, pp. 130$137,1980$.

[82] F. Wang, A. Tessier, and H. Landies, Oxygen measurements in the burrows of fresh water insects-. Freshwater Biol. -46, 317$327,2001$.

[83] W. K. Dodds, Fresh water ecology: concepts and environmental application. In: Aquatic Ecological Series. Academic press, San Diego, 2002.

[84] A. H. Roy, A. D. Rosemond, M. J. Paul. D. S. Leigh, and J. B. Wallace. Stream macroinvertebrates response to catchment Urbanization (Georgia, USA), 2003.

[85] S. M. Mandaville. Benthic Macroinver tebrates in Freshwaters-Taxa Tolerance Values, Metrics, and Protocols6 Dartmouth: Soil \& Water Conservation Societies of Metro Halifax. 2000.

[86] M. T. Barbour, J. Gerritsen, B. D. Snyder, and J. B. Stribling, Rapid Bioassessment Protocols for Use in Streams and Wadeable Rivers: Periphyton, Benthic Macroinvertebrates and Fish, Second Edition. EPA U. S. Environmental Protection Agency, Office of Water, Washington, EPA. D. C. 841-B-99002, 1999.

[87] S. Linke, R. Bailey, andI. J. Schwindt. Temporal variability of stream bioassessments using benthic macro-invertebrates. Fresh water Biol. -42, 575-584, 1999.

[88] S. J. Ormerod, The influences of habitat and seasonal sampling regims on the ordination and classification of macroinvertebrates assemblages in the catchment of the River Wye, Wales. Hydrobiologia 150: 143-151, 1987.

[89] M. T. Furse, D. Moss, J. W. Wright and P. D. Armitage. The influence of seasonal and taxonomic factors on the ordination and classification of running water sites in Great Britain and on the prediction of their macroinvertebrate communities. Fresh water biology 1414: 257-280, 1984. 